\title{
A Comparison of the Effectiveness of Pitfall and Longworth Live-trapping Techniques in Population Studies of House Mice
}

\section{Grant R. SINGLETON}

Singleton G. R., 1987: A comparison of the effectiveness of pitfall and Longworth live-trapping techniques in population studies of house mice. Acta theriol., 32, 15: 245-259 [With 3 Tables \& 4 Figs.].

A population of house mice (Mus musculus Linnaeus, 1758) on a cereal farm in Australia was trapped for 6 months during a period of rapid population growth using Longworth and several designs of pitfall live-traps. The most effective method of capturing mice in pitfall traps was by interconnecting the pitfalls with a drift fence that was positioned over the centre of each trap. Pitfall traps without fences and those prebaited for five weeks, caught few mice. The trappability of mice ranged from 30 to $40 \%$ for pitfalls and from 11 to $20 \%$ for Longworths, indicating the mice may have a greater tendency to avoid repeated captures in Longworths than in pitfalls. Both trapping methods were effective in sampling all age classes of mice. Overall, mice caught in pitfall traps were not significantly lighter or smaller than those caught in Longworth traps. The results of this study indicate that the two trapping methods provided similar, although independent, samples of a mouse population.

[Division of Wildlife \& Rangelands Research. CSIRO, P.O. Box 84, Lyneham, A.C.T. 2602, Australia]

\section{INTRODUCTION}

Most demographic studies of small mammals rely heavily on information obtained from live-trapping techniques. An assumption in the analysis and interpretation of live-trapping data is that trappable members of a given population respond similarly to a particular trapping method. The use of different trapping methods provides a test of this assumption (Boonstra \& Krebs, 1978). In population studies of Microtus townsendii (Bachman, 1839) pitfall live-traps (pitfalls) and Longworth live-traps (Longworths) captured different segments of the population and many of the young voles caught in pitfalls never entered Longworths (Beacham \& Krebs, 1980; Boonstra \& Krebs, 1978). In contrast, in a population study of Microtus pennsylvanicus (Ord, 1815) Longworths were found to be more effective than pitfalls, although first capture of young voles occurred more often in pitfalls (Boonstra \& Rodd, 1984). Andrzejewski \& Rajska (1972) found live-traps (dimensions $160 \times 100 \times$ $\times 100 \mathrm{~mm}$, see Olszewski, 1968) more effective than pitfalls in capturing Clethrionomys glareolus (Schreber, 1780); and although the trappability 
in the former increased with age of bank voles, that in the latter was low across all age classes. It is clear from these studies that a response to a particular trapping method cannot be extrapolated across species.

This study addresses initially the effectiveness of different pitfall trapping methods (e.g. with or without drift fences) for capturing house mice, Mus musculus (Linnaeus, 1758) and then compares the effectiveness of the best pitfall method with that of the Longworth live-trap.

\section{STUDY AREA}

The study area was part of the Mallee Research Station at Walpeup in the central Mallee wheatlands of northwestern Victoria, Australia. This region is extensively farmed and main crops are the winter cereals, wheat and barley. The study was conducted during the period January 1984 to July 1984, in a stubble paddock which had been sown to ryecorn (Triticale sp.) and wheat (Triticum aestivum) in May 1983 and harvested in November 1983 (Fig. 1).

\section{MATERIALS AND METHODS}

\subsection{Pitfall Trap Designs}

(a) Drift fences. The drift fence consisted of a $400 \mathrm{~mm}$ high fence of fine mesh aluminium fly-screen and ran between pitfalls of each line. The drift fence cut across the centre of pitfalls except for prebaited pitfalls where the fence was offset to one side.

(b) Prebaiting versus baiting traps when set. From January to April a subsample of pitfalls was fitted with a prebaiting platform similar to a design described by Boonstra and Krebs (1978). Pitfalls were prebaited for the five weeks between trapping periods by adding wheat and oats to a platform suspended $100 \mathrm{~mm}$ from the top of the pitfall. The platform was covered and the cover was raised from the ground allowing ad libitum access to the bait. The bait was checked weekly, and additional grain added if required. Pitfalls not prebaited were baited when set; wheat was added to and lightly sprinkled around each pitfall.

(c) Trap diameter. Two types of pitfalls were used; one $390 \mathrm{~mm}$ in diameter and $455 \mathrm{~mm}$ deep and the other $300 \mathrm{~mm}$ in diameter and $580 \mathrm{~mm}$ deep. Both types were placed along the drift fence which had 15 pitfalls, eight were $390 \mathrm{~mm}$ in diameter and seven (two prebaited) were $300 \mathrm{~mm}$ in diameter.

\subsection{Pitfall Trapping Schedules}

Two trapping arrangements were used: (1) A line of 15 fenced pitfalls plus nine scattered and unfenced pitfalls were set in the stubble paddock in January 1984. (2) From April to July 1984 a new trapping arrangement was used. Three solitary, unfenced pitfalls, and two fenced pitfall trapping lines, one containing 15 pitfalls and the other 10, were set. Pitfalls along the drift fences were placed, on average, $5 \mathrm{~m}$ apart (Fig.1). The schedule of pitfall trapping is shown in Figure 2. A $200 \mathrm{~mm}$ length of $45 \mathrm{~mm}$ diameter PVC pipe was placed in the bottom of each pitfall to provide shelter from rain and protection from foxes and avian predators. 
Pitfalls versus Longworth trapping of mice

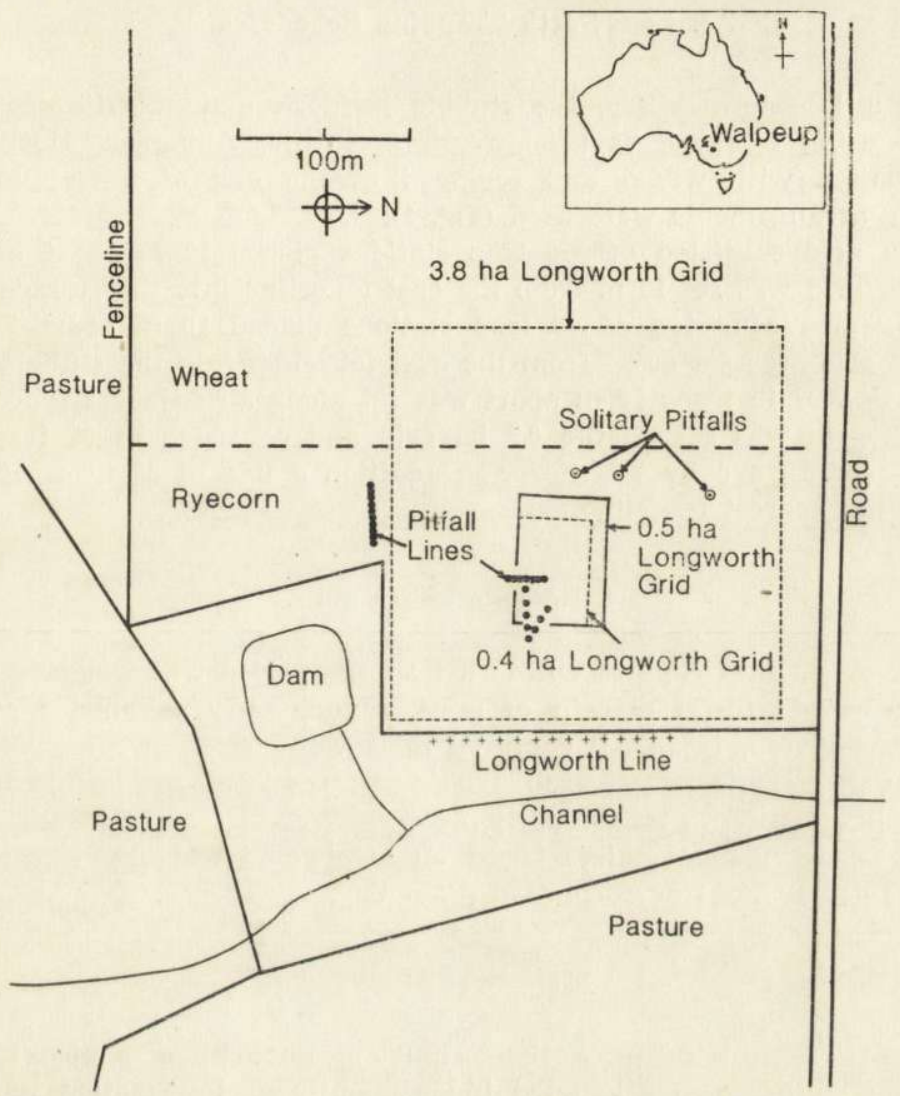

Fig. 1. The location of the three Longworth grids, the Longworth line (east fenceline), the pitfall lines (closed circles) and the solitary pitfalls (open circles) at the Mallee Research Station.

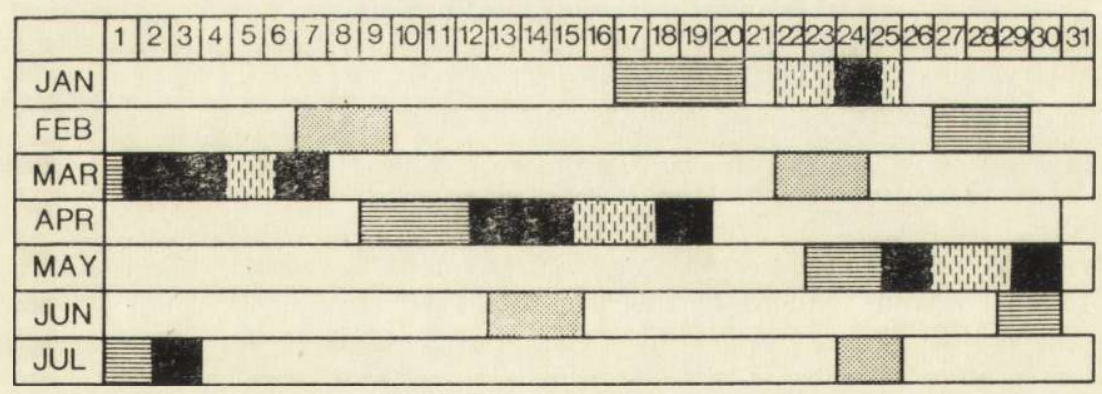

0.5 ha Longworth Grid

Pitfalls
3.8 ha Longworth Grid

П 0.4 ha Longworth Grid

Fig. 2. Summary of the Longworth and pitfall trapping schedule. 


\subsection{Longworth Trapping Schedules}

As part of a long-term study, the stubble paddock and an adjacent fenceline were trapped using Longworths (Longworth Scientific, Abingdon, U.K.) (Fig. 2). These were baited with wheat and removed at the end of a trapping period. Three trapping arrangements were used (Fig. 1):

(1) A 3.8 ha grid consisted of 256 trap stations placed $15 \mathrm{~m}$ apart in a 16 by 16 pattern. The grid was set $15 \mathrm{~m}$ from the east fenceline into the stubble paddock.

(2) A 0.5 ha grid consisted of 48 trap stations placed $10 \mathrm{~m}$ apart in a 6 by 8 pattern. The grid was set $60 \mathrm{~m}$ from the east fenceline into the stubble paddock. In addition a line of 15 traps $10 \mathrm{~m}$ apart was set along an adjacent fenceline.

(3) A 0.4 ha grid was set on the 0.5 ha grid and consisted of 35 trap stations placed $10 \mathrm{~m}$ apart in a 5 by 7 pattern. In addition a line of 35 traps $10 \mathrm{~m}$ apart was set along the nearest fenceline.

\subsection{Demographic Data}

Each mouse on its first capture within a trapping period was weighed, measured from tip of snout to distal margin of anus, sexed, and examined for breeding condition (see Singleton, 1983). All captured mice were ear-tagged and toe-clipped. Location, date, tag number and trap type were recorded for each capture. As there was much variation in the proportion of Longworths entered by mice between trapping periods, abundance indices based on Longworth trapping were estimated using a density-frequency transformation (Caughley, 1977 p. 20).

\subsection{Statistical Analyses}

Trappability was estimated using the formula of Boonstra \& Krebs (1978). Each estimate of trappability was calculated independently of information provided by the other trap type. Because trappability could be affected by the spatial arrangement of the trapping grids, a trappability estimate for the 3.8 ha Longworth grids (traps $15 \mathrm{~m}$ apart) was estimated independently of information obtained from the 0.5 and 0.4 ha Longworth grids (traps $10 \mathrm{~m}$ apart).

The effect of prebaiting on number of mice caught per pitfall trap night was examined by a balanced three-way analysis of variance (ANOVA) which comprised two fixed factors (prebaited, fenced) and a random factor (trap rounds). The effect of each fixed factor was determined by testing against the respective interaction term. The effect of drift fences and differences in diameter of pitfall openings on number of mice caught per pitfall trap night, were analysed separately by two way-ANOVA's. In each case, "fenced" or "diameter" was the fixed factor and "trap round" was a random factor. The effect of each fixed factor determined by testing against the respective interaction term. In all of these ANOVA's, some estimates of mice caught per pitfall trap night per treatment were zero, therefore all estimates were transformed by the equation $\mathrm{x}=\log (\mathrm{x}+0.1)$.

Movement patterns were analysed by an unbalanced two-way ANOVA. Movement distances included values of zero and one; these approximated better a Poisson than a normal distribution. Therefore, all values were transformed prior to ANOVA by adding $5 / 8$ to each value and then transforming the variates to square roots.

Multiple linear regression analysis was used to examine mean body weight and mean body length of mice with respect to sex, trap round and trap type 


\section{RESULTS}

\subsection{Pitfall Trap Designs}

The number of mice caught in the four designs of pitfalls across the five trapping rounds is presented in Table 1. Over the five trapping rounds, 2-way ANOVA's indicated that: (1) the diameter of the pitfall opening (300 $\mathrm{mm}$ or $390 \mathrm{~mm}$ ) had no significant effect on the number of mice caught $(F 1,2=1.46, p>0.50)$. Therefore, mice caught in the two pitfall types were combined for the comparisons of the four pitfall designs. (2) pitfalls connected by a drift fence caught significantly more mice than pitfalls with no fence $(F 1,4=11.18 p<0.05)$.

\section{Table 1}

Number of mice caught in the various pitfall designs over the five trap rounds. Number of pitfall trap nights per treatment is shown in parentheses,

\begin{tabular}{|c|c|c|c|c|c|}
\hline \multirow{2}{*}{$\begin{array}{l}\text { Trap } \\
\text { round }\end{array}$} & \multirow{2}{*}{$\begin{array}{l}\text { No fence } \\
\text { prebait }\end{array}$} & \multirow{2}{*}{$\begin{array}{l}\text { No fence } \\
\text { No prebait }\end{array}$} & \multirow{2}{*}{$\begin{array}{c}\text { Fence } \\
\text { Prebait }\end{array}$} & \multicolumn{2}{|c|}{ Fence + no prebait } \\
\hline & & & & 300 diam. & 390 diam. \\
\hline 1 & 0 (15) & $\begin{array}{ll}0 & (6)\end{array}$ & $1 \quad(4)$ & $7(10)$ & $9(16)$ \\
\hline 2 & 1 (25) & 4 (15) & 3 (10) & $18(25)$ & $24(40)$ \\
\hline 3 & $9(24)$ & $33(40)$ & $4(12)$ & $22(30)$ & $72(48)$ \\
\hline 4 & & $0 \quad(8)$ & & $116(28)^{\mathrm{a}}$ & $119(27)^{a}$ \\
\hline 5 & & $0 \quad(6)$ & & $41(14)^{a}$ & $128(14)^{\mathrm{a}}$ \\
\hline
\end{tabular}

a Does not include mice caught in the second fenced line of 10 pitfalls.

For trap rounds 1 to 3, a 3-way ANOVA (prebait, drift fence, trap round) indicated that: (1) pitfalls connected by a drift fence caught significantly more mice $(F 1,2=24.11, p<0.05)$. (2) prebaiting did not have a significant effect on capture rate $(F 1,2=14.56,0.10>p>0.05)$.

There were no significant interaction effects. The high $\mathrm{F}$ value for the factor "prebaited" may simply reflect the low number of replicates in this study and indicates that this factor needs more study. Fewer mice were caught in the prebaited pitfalls.

\subsection{Population Dynamics}

The following demographic information was obtained from the 0.5 ha and 0.4 ha grids. A rapid increase in mouse abundance began during the summer of $1983 / 84$ (December to February) and continued through to late autumn (May). Mouse abundance remained high until the end of the study in July 1984 (Fig. 3). 
Breeding began at the study site in September 1983. In March 1981 $40 \%$ of adult (head body length $>72 \mathrm{~mm})$ females $(n=95)$ were pregnant $(21 \%)$ or lactating, in April $50 \%$ of adult females $(N=127)$ were pregnant $(4 \%)$ or lactating, and in May only $2 \%$ of adult females $(n=207)$ were pregnant $(1 \%)$ or lactating.

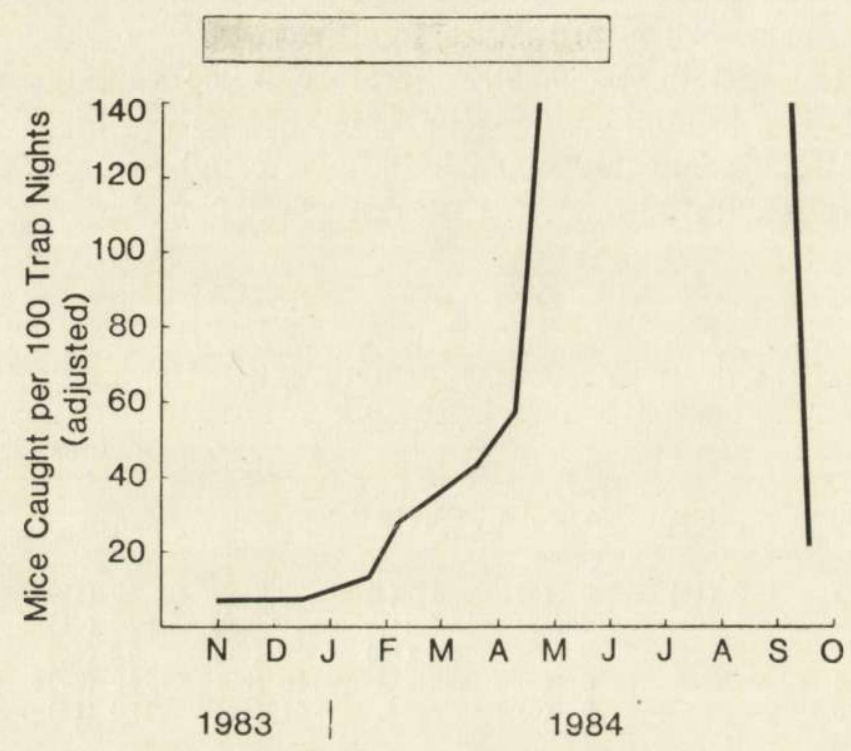

Fig. 3. Mouse abundance on the Mallee Research Station, November 1983 to September 1984. The index of mouse abundance was greater than 140 from May to August 1984. Extent of breeding season is represented by the shaded bar.

\subsection{Body Length and Weight Comparisons}

Only $7 \%$ of the variance in multiple linear regression analysis of mean body weight on first capture of mice per trap round, was accounted for by a model which included the factors sex, trap round and trap type. Analysis of variance of these data indicated significant interactions between trap round and $\operatorname{sex}(F 4,2855=2.37, p<0.01)$, and trap round and trap type $(F 4,2855=6.82, p<0.01)$. Consideration of each factor as a separate component is not possible because these interaction terms are contributing significantly to the overall variance and the experimental design is not orthogonal. Similarly, only $7 \%$ of the variance in mean body length was accounted for by a model including the above factors. Analysis of variance of these data indicate significant interactions between trap round and sex $(F 4,2848=7.88, p<0.01)$, and sex and trap type $(F 4,2848=12.25, p<0.01)$. For first captures of mice per trap round, 
Longworth captured males were on average $1.7 \mathrm{~g}$ heavier (range 0.6 to 2.4 ) and $2.7 \mathrm{~mm}$ longer (range 1.4 to 5.4 ) over trap rounds 1 to 4 , but were $0.9 \mathrm{~g}$ lighter and $1.9 \mathrm{~mm}$ longer in trap round 5 , and females were $2.0 \mathrm{~g}$ heavier (range 0.7 to 3.2 ) and $2.3 \mathrm{~mm}$ longer (range 0.2 to 4.6 ) over all trap rounds than males and females respectively, caught in pitfalls (Table 2).

Table 2

Mean body weight $(\mathrm{g})$ and mean body length $(\mathrm{mm})$ of first captures of mice in each trap round for each sex and trap type, and of recaptures of mice within a trap round for each sex and trap type, over the five trap rounds. $\mathrm{N}=$ sample size, $\mathrm{Wt}=$ mean weight; Lgth $=$ mean length.

\begin{tabular}{|c|c|c|c|c|c|c|c|c|c|c|c|c|}
\hline \multirow{3}{*}{$\begin{array}{l}\text { Trap } \\
\text { round } \\
\& \text { sex }\end{array}$} & \multicolumn{6}{|c|}{ First captures } & \multicolumn{6}{|c|}{ Recaptures within a round } \\
\hline & \multicolumn{3}{|c|}{ Longworths } & \multicolumn{3}{|c|}{ Pitfalls } & \multicolumn{3}{|c|}{ Longworths } & \multicolumn{3}{|c|}{ Pitfalls } \\
\hline & $\mathrm{N}$ & Wt & Lgth & $\mathrm{N}$ & Wt & Lgth & $\mathrm{N}$ & Wt & Lgth & $\mathrm{N}$ & Wt & Lgth \\
\hline 1 & & & & & & & & & & & & \\
\hline Males & 166 & 16.4 & 80.4 & 12 & 14.0 & 78.7 & 46 & 16.9 & 80.9 & 0 & & \\
\hline $\begin{array}{c}\text { Females } \\
2\end{array}$ & 86 & & & 5 & & & 1 & & & 0 & & \\
\hline Males & 284 & 13.5 & 74.9 & 20 & 11.9 & & 32 & 13.6 & 75.1 & 2 & 12.6 & 73. \\
\hline$\underset{3}{\text { Females }}$ & 203 & 14.9 & & 27 & & & 24 & & & 2 & 17.2 & \\
\hline Males & 265 & 14.3 & 77.6 & 58 & 11.9 & & 41 & 16.6 & & 6 & 15.7 & 81.0 \\
\hline$\underset{4}{\text { Females }}$ & 250 & & & 73 & & & 29 & 16.7 & & 4 & 12.5 & \\
\hline Males & 381 & 14.2 & 77. & 133 & 13.6 & 75. & 61 & 14. & 78 & 29 & 12.2 & 73 \\
\hline$\underset{5}{\text { Females }}$ & 386 & 16.2 & 80.7 & 120 & 15.0 & 78.4 & 103 & 17.8 & 83.0 & 25 & 14.3 & \\
\hline Males & 8 & & & 112 & & & & & & 11 & & 79. \\
\hline Females & 110 & 15.8 & 79.6 & 92 & 15.1 & 79.4 & 33 & 16.8 & 81.7 & 6 & 14.2 & \\
\hline
\end{tabular}

Size distribution of mice varied throughout the six month study. Also, size distribution within a trapping round was generally different for males and females. This was most evident in trap round 4; females exhibited a bimodal and males a unimodal size distribution in captures by Longworths and pitfalls. Despite these differences in size distribution there was no obvious size class in either sex missing from or additional to those caught in Longworth versus pitfall traps (Fig. 4).

Only $15 \%$ of the variance in regression analysis of mean body weight cf mice recaptured within trap rounds was accounted for by a model including the factors sex, trap type and trap round. Analysis of variance of these data indicate a significant interaction between sex and trap round $(F 4,478=2.98, p<0.05)$ and that mice recaught in Longworths were significantly heavier than mice recaught in pitfalls $(F 1,478=25.0$, $p<0.01$ ). Regression analysis of mean body length accounted for $12 \%$ of the variance. Analysis of variance of these data indicated a significant 
interaction between sex and trap round $(F 4,479=2.81, p<0.05)$ and that mice recaught in Longworths were significantly longer than mice recaught in pitfalls $(F 1,479=22.88, p<0.001)$. The largest sample was obtained in trap round 4 when males recaught in Longworths were $2.6 \mathrm{~g}$ heavier and $4.5 \mathrm{~mm}$ longer, and females recaught in Longworths were $3.5 \mathrm{~g}$ heavier and $6.6 \mathrm{~mm}$ longer than those recaught in pitfalls (Table 2).

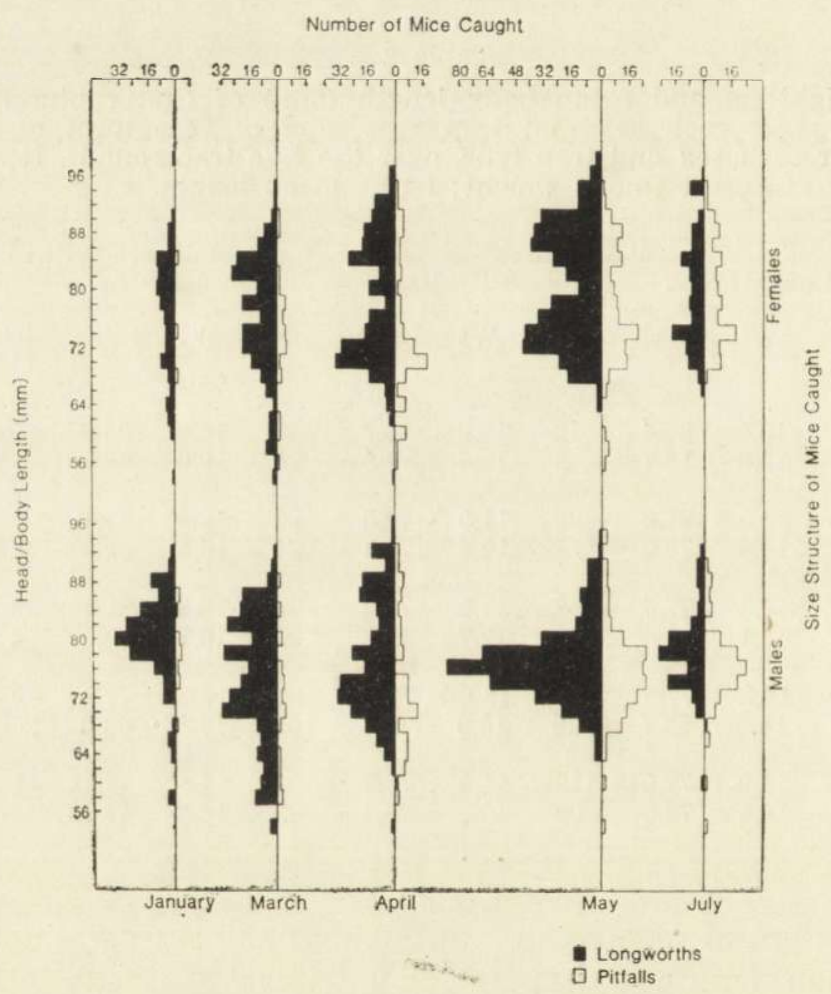

Fig. 4. Size distribution of males and females caught in Longworths (shaded) and pitfalls (unshaded) over the five trap rounds.

\subsection{Mice Caught in Both Trap Types}

Over the five trapping rounds 495 different mice were caught first in pitfalls; of these, $29(6 \%)$ were re-caught in Longworths. The proportion of animals first caught in Longworths that were re-caught in pitfalls was 7\% (139 of 1908 mice).

Of the few juveniles and sub-adults caught in both trap types, $61 \%$ of those first caught in Longworths $(n=23)$ and $63 \%$ of those first caught in pitfalls $(n=8)$ were re-caught in the second trap type within 5 weeks. 
A short time-lag between captures in the two trap types was apparent also amongst both sexes of the adult age class. Seventy-six percent of both male $(n=58)$ and female $(n=58)$ adults first caught in Longworths were re-caught in pitfall traps within 5 weeks; all adults first caught in pitfalls $(n=21)$ entered Longworths within 5 weeks.

Mean captures per mouse of those caught more than twice, were similar across all combinations of trap type, time period and grid size (Table 3).

Analyses of movement patterns of mice reflected similar mean distances moved by mice within a sampling round (Longworths to pitfalls mean $=35.9 \pm 3.81 \mathrm{~m}, n=102$; pitfalls to Longworths mean $=34.8 \pm 5.38 \mathrm{~m}$, $n=18)$ and different mean distances moved by mice between sampling rounds (Longworths to pitfalls mean $=49.6 \pm 6.53 \mathrm{~m}, n=47$; pitfalls to

Table 3

Trappability estimates, sample sizes, and mean captures of mice caught more than twice, for each trap type and for two sample periods.

\begin{tabular}{|c|c|c|c|c|c|}
\hline $\begin{array}{l}\text { Trap type } \\
\text { \& sex }\end{array}$ & Period & $\begin{array}{l}\text { No. } \\
\text { different } \\
\text { mice } \\
\text { caught }\end{array}$ & $\begin{array}{l}\text { No. mice } \\
\text { potentially } \\
\text { caught } \\
>\text { twice }\end{array}$ & $\begin{array}{c}\text { Mean captures } \\
\text { of mice } \\
\text { caught } \\
>\text { twice }\end{array}$ & $\begin{array}{c}\text { Trappability } \\
(\%)\end{array}$ \\
\hline \multicolumn{6}{|l|}{ Pitfall } \\
\hline Males & January & 209 & 27 & $3.3(0.13)$ & 37.8 \\
\hline Females & to July & 207 & 19 & $3.7(0.26)$ & 37.4 \\
\hline \multicolumn{6}{|l|}{ Longworth } \\
\hline Males & & 1029 & 176 & $4.0(0.18)$ & 11.2 \\
\hline \multirow{2}{*}{\multicolumn{6}{|c|}{ Pitfall }} \\
\hline & & & & & \\
\hline Males & January & 126 & 17 & $3.2(0.15)$ & 40.9 \\
\hline Females & to May & 133 & 13 & $3.6(0.26)$ & 30.4 \\
\hline \multicolumn{6}{|l|}{ Longworth } \\
\hline Males & & 789 & 147 & & 11.0 \\
\hline Females & & 631 & 136 & & 19.9 \\
\hline \multicolumn{6}{|l|}{ (1) $3.8 \mathrm{ha}$ grid } \\
\hline Males & & 522 & 66 & $3.7(0.17)$ & 18.8 \\
\hline Females & & 404 & 66 & $3.5(0.12)$ & 22.8 \\
\hline \multicolumn{6}{|c|}{ (2) $0.5 \& 0.4$ ha grid } \\
\hline Males & & 289 & 59 & $3.8(0.21)$ & 23.3 \\
\hline Females & & 245 & 52 & $4.1(0.24)$ & 23.1 \\
\hline
\end{tabular}

Longworths mean $=25.1 \pm 6.29, n=28$ ). However, apart from mice previously caught in Longworths moving significantly longer distances to enter a pitfall between sampling rounds $(F 1,145=3.94, p<0.05)$, there were no significant differences in distances moved by mice between the two trap types with respect to capture order $(F 1,191=0.08, p>0.05)$, trap rounds $(F 1,191=3.27, p>0.05)$, or the interaction between trap round and capture order $(F 1,191=3.27, p>0.05)$. 
Capture in Longworths would depend also on the availability of empty traps; 70, 48, 41, 4 and 0 per cent respectively, of Longworths were unoccupied in trap rounds 1 to 5 .

\subsection{Trappability}

Trappability of males and females was similar in both trap types, between January and July. In the same period, males were 3.4 times and females were 2.4 times more trappable in pitfalls than Longworths, yet the proportion of mice potentially caught more than twice in either trap type was higher for each sex in mice caught in Longworths (Table 2). Trappabilities were similar on the large and small Longworth grids.

\section{DISCUSSION}

\subsection{Effectiveness of Different Pitfall Designs}

There have been no previous studies of the effectiveness of pitfalls for capturing house mice. The studies most relevant to the present work are those comparing the effectiveness of Longworth and pitfall traps in populations of $M$. townsendii (Boonstra \& Krebs, 1978; Beacham \& Krebs, 1980 ) and $M$. pennsylvanicus (Boonstra \& Rodd, 1984). In these studies pitfalls were prebaited and unfenced. Unfenced pitfalls, prebaited or not, caught few house mice in the present study. Trapping of mice was greatly enhanced by a drift fence positioned across the middle of each pit. Prebaiting resulted in fewer mice caught, however, the placement of a prebaiting platform along a drift fence necessitated prebaited pitfalls to be offset from the fence. The position of the drift fence over the centre of the pit may be more important than prebaiting if pitfalls are to be effective traps for mice.

\subsection{Population Densities}

Population densities estimated in the studies of Microtus species (loc. cit.) could be compared readily because a pitfall trap was placed at each Longworth grid point. A more simple design of pitfall trap placement was chosen in the present study because of expense, time and design problems involved in placing a pitfall at each Longworth grid point and then positioning drift fences between them. Consequently, the contrast in spatial configuration between the two trap types in the present study rendered meaningless any comparison of population densities calculated 
from the two trapping methods. However, important demographic information essential for comparison of the effectiveness of the two trapping methods in capturing house mice was obtained.

\subsection{Weight, Size and Age Structure Comparisons}

Overall, mice caught in pitfalls were approximately $2 \mathrm{~g}$ lighter and $2.5 \mathrm{~mm}$ shorter than those caught in Longworths. However, significant interactions between sex and trap round, and between trap round and trap type indicated that weight and length differences between mice caught in pitfalls and Longworths varied considerably over the five trapping rounds. Weight and length differences were most pronounced in a young population. Despite these differences, the most common size classes of mice caught during each trap round were similar for both types of trap. Also, the time-lag between when young mice entered a pitfall and then entered a Longworth was generally less than five weeks, the minimum time between trap rounds.

Competition for live-traps has been reported in a number of small mammal species; larger, dominant individuals usually being more trappable than smaller subordinate individuals (Kikkawa, 1964; Gliwicz, 1970; Summerlin \& Wolfe, 1973). The level of competition for traps in a population of $C$. glareolus increased as the density of trappable animals increased (Kikkawa, 1964). If there was a positive association between social dominance and trappability in the present study, then competition would be expected to be intense in the latter trap rounds when all but a few Longworths were occupied each night and the smaller size classes of mice would be noticeably underrepresented amongst those caught in Longworths compared to those caught in pitfalls. However, the smaller size classes of mice were not underrepresented in Longworth captures in trap rounds 4 and 5, suggesting that Longworth and pitfall traps are equally effective in sampling all age classes of the population. The two trap types appeared to be providing similar, although independent, samples of a mouse population.

\subsection{Movements Between Trap Types}

Comparison of overlap in captures between the two trap types is compounded because the Longworths were set over a larger trapping area and the two trap types were generally not set concurrently. Even so, there was no evidence that capture in either trap type affected the likelihood of capture in the other. This is surprising. The opportunity for mice to move from pitfall to Longworth traps was reduced because: 
(i) half of the pitfall trapping effort occurred at the end of a trap round during which time no Longworths were set, and (ii) there was intense ccmpetition for empty Longworths in trap rounds 4 and 5 when all but a few traps were full each night. If the latter had an effect one would expect the distances moved by mice from pitfalls to Longworths within a trap round to be longer than the reverse movements. This was not the case; the respective mean distances moved between trap types were similar. However, there was a large difference between trap rounds in mean distance of mouse movements between trap type; mice moved twice as far between Longworths and pitfalls than between pitfalls and Longworths. The reason for this difference is not apparent.

\subsection{Trappability}

Repeated captures of $M$. townsendii and $M$. pennsylvanicus in pitfalls range from 5 to $35 \%$, whereas trappability in Longworths was greater than 50\% (Boonstra \& Krebs, 1978; Beacham \& Krebs, 1980; Boonstra $\&$ Rodd, 1984). My results indicate an opposite trap response; mice had a greater tendency to avoid repeated captures in Longworth than in pitfalls. However, this tendency should be viewed with caution. Firstly, the measures of trappability of mice in Longworths were underestimated because of the competition for empty traps in the latter trapping rounds. Secondly, although trappability of mice in Longworths was only marginally influenced by length of sample period, periodicity of trapping and/or spatial layout of traps, significant changes in trappability may have occurred if the spatial layout of Longworths had been changed from a grid to a line. Trappability in voles may be modified by the trapping regime (Krebs \& Boonstra, 1984), consequently, comparisons of trappability of house mice between pitfall trap lines and Longworth trapping grids may not be valid.

\subsection{Comparison with Microtus Studies}

The differences in effectiveness of Longworths compared to pitfalls in capturing mice are small relative to those reported in voles. Longworths generally caught $M$. townsendii over $40 \mathrm{~g}$ whereas pitfalls generally caught animals under $40 \mathrm{~g}$, there was a time lag of 5 to 9.3 weeks between first capture in a pitfall and later capture in a Longworth, and pitfalls captured over $70 \%$ and Longworths $55-60 \%$ of the population (Boonstra \& Krebs, 1978; Beacham \& Krebs, 1980). More M. pennsylvanicus juveniles $(<22 \mathrm{~g})$ were captured in pitfalls and more adults 
$(>33 \mathrm{~g})$ were captured in Longworths, there was a time lag of 4 to 6 weeks between first capture in a pitfall and later capture in a Longworth, and Longworths captured $82 \%$ and pitfalls $46 \%$ of the population (Boonstra \& Rodd, 1984).

The studies of voles differed from that of mice. Design and spatial layout of the pitfalls were different, vole populations were trapped more frequently, Longworth traps were locked open and left in situ between trap rounds, the North American grassland habitats in which the vole studies were conducted were very different to the Mallee wheatland habitat of southeastern Australia, and mice are at least twice as small as voles. The latter point is noteworthy. The lightest weight classes of: mice captured in Longworths (minimum weight $4.5 \mathrm{~g}$ ) may be underrepresented because the triggers of some traps may nat be sufficiently sensitive. Deermice, Peromyscus maniculatus, (Wagner, 1845) are similar in weight to house mice, but weight classes below $7.5 \mathrm{~g}$ violated the assumption that all traps are equally efficient at capturing this species (Grant, 1970). Particular attention was paid to setting the trigger finely in every trap in the present study. This form of trap capture bias would be minimal in the heavier voles. Therefore it is not surprising that the response of house mice to the two trap types is different to that reported for voles.

\subsection{Concluding Remarks}

The present study was conducted principally on high density mouse populations. Pitfalls were as effective as Longworths in providing a sound data base for demographic studies when mouse density was high. At lower densities pitfalls may be as effective as Longworths but they may be far less efficient; for similar time and effort, Longworth trapping covers a much larger area and many more traps may be set. Further comparative studies of the two trapping methods are required during periods of low mouse population density.

Drift fences are necessary for pitfall trapping of house mice to be as effective as Longworth trapping. Although neither Longworths nor pitfalls captured a large proportion of the mouse population during the period of rapid population increase, they both provided consistent quantitative estimates of the various demographic parameters, in a relative rather than an absolute sense. The small difference in response of mice to the two trapping methods is in contrast to the pronounced differences reported in $M$. townsendii and to a lesser extent in $M$. pennsylvanicus. Variation in design between the present mouse study and the three vole 
studies may account for some of this contrast in trap response. However, given the pronounced interspecies differences in Microtus in response to trap types, marked inter-family differences are not surprising.

Acknowledgements: I thank Dr. Trevor Redhead for his advice and enthusiasm throughout the study, and Drs. Caughley and Redhead for their assistance in the analyses of the data. Kathy Masters, Ross Cooper and Colin Tann provided expert field assistance and formed a team of excellent and enthusiastic workers. Drs. Boonstra, Redhead and Spratt provided helpful suggestions and critical discussion of an earlier draft of the manuscript. My appreciation is also extended to John Griffiths and his staff for their assistance during my work at the Mallee Research Station. I thank Glenn Schipp for drawing the diagrams. This research was funded by the Wheat Research Council of Australia, project number CS44.

\section{REFERENCES}

1. Andrzejewski R. \& Rajska E., 1972: Trappability of bank voles in pitfalls and live traps. Acta theriol., 17: $41-56$.

2. Beacham T. D. \& Krebs C. J., 1980: Pitfall versus live-trap enumeration of fluctuating populations of Microtus townsendii. J. Mammal., 61: 486-499.

3. Boonstra R. \& Krebs C. J., 1978: Pitfall trapping of Microtus townsendii. J. Mammal., 59: 136-148.

4. Boonstra R. \& Rodd F. H., 1984: Efficiency of pitfall versus live traps in enumeration of populations of Microtus pennsylvanicus. Can. J. Zool., 62: $758-165$.

5. Caughley G. C., 1977: Analysis of vertebrate populations. John Wiley \& Sons, London, New York, Sydney \& Toronto.

6. Gliwicz J., 1970: Relation between trappability and age of individuals in a population of the bank vole. Acta theriol., 15: 15-23.

7. Grant P. R., 1970: A potential bias in the use of Longworth traps. J. Mammal., 51: $831-835$.

8. Kikkawa J., 1964: Movements, activity, and distribution of the small rodents Clethrionomys glareolus and Apodemus sylvaticus in woodland. J. Anim. Ecol., 33: $259-299$.

9. Krebs C. J. \& Boonstra R., 1984: Trappability estimates for mark-recapture data. Can. J. Zool., 62: 2440-2444.

10. Olszewski J. L., 1968: Role of uprooted trees in the movements of rodents in forests. Oikos, 19: 99-104.

11. Singleton G. R., 1983: The social and genetic structure of a natural colony of house mice, Mus musculus, at Healesville Wildlife Sanctuary. Aust. J. Zool., 31: $155-166$.

12. Summerlin C. T. \& Wolfe J. L., 1973: Social influence on trap response of the cotton rat, Sigmodon hispidus. Ecology, 54: 1156-1159.

Received 1 June 1986, Accepted 3 March 1987. 
Grant R. SINGLETON

POROWNANIE EFEKTYWNOSCI DWU TYPOW PUŁAPEK ZYWOŁOWNYCH W BADANIACH POPULACYJNYCH MYSZY DOMOWEJ

\section{Streszczenie}

Populacja myszy domowej (Mus musculus Linnaeus, 1758) zasiedlająca pole zboża wokół farmy w Australii badana była przez 6 miesięcy w czasie szybkiego wzrostu liczebności. Użyto dwa typy pułapek żywołownych. Najefektywniejszą metodą okazało się połączenie cylindrów $\mathrm{z}$ płotkiem przegradzającym umieszczonym wzdłuż średnicy pułapki. Cylindry bez płotków oraz cylindry z przynętą wykładaną przez 5 tygodni przed odłowami złowiły niewiele myszy (Tabela 1). Częstość ponownych złowień wahała się od 30 do $40 \% \mathrm{w}$ przypadku cylindrów oraz od 11 do $20 \% \mathrm{w}$ przypadku pułapek Longwortha, co może wskazywać, że myszy bardziej unikają powtórnych złowień w pułapki Longwortha, niż w cylindry. Obie metody były jednakowo skuteczne w lowieniu wszystkich klas wiekowych myszy domowej. Osobniki schwytane w cylindry nie były istotnie mniejsze i lżejsze od osobnikow złowionych w pułapki Longwortha (Tabela 2). Oba typy pułapek dostarczają więc podobne, choć niezależne, próby z populacji myszy domowej. 